\title{
Lessons from the Bone Chapter of the Malaysian Aging Men Study
}

\author{
Kok-Yong Chin ${ }^{1}$, Wan Zurinah Wan Ngah $^{2}$ and Soelaiman Ima-Nirwana ${ }^{1, *}$ \\ 1 Department of Pharmacology, Faculty of Medicine, Universiti Kebangsaan Malaysia, Kuala Lumpur 56000, \\ Malaysia; chinkokyong@ppukm.ukm.edu.my \\ 2 Department of Biochemistry, Faculty of Medicine, Universiti Kebangsaan Malaysia, Kuala Lumpur 56000, \\ Malaysia; wwanzurinah@yahoo.com \\ * Correspondence: imasoel@ppukm.ukm.edu.my; Tel.: +60-3-9145-5002
}

Academic Editors: Marlena Kruger and Hope Weiler

Received: 26 March 2016; Accepted: 23 May 2016; Published: 25 May 2016

\begin{abstract}
Male osteoporosis in Malaysia is a largely neglected problem. Therefore, a bone health study in men using quantitative ultrasonometry was launched as part of the Malaysian Aging Men Study in 2009-2012. This review aimed to summarize the findings of the aforementioned bone health study. The study examined the bone health of Chinese and Malaysian men aged 20 years and above living in Kuala Lumpur using a quantitative ultrasound device. Participants answered a questionnaire on their demographic details and physical activity status. Body anthropometry of the participants was measured and their blood collected for biochemical analysis. Results showed that a significant proportion of the Malaysian Chinese and Malay men had suboptimal bone health indicated by calcaneal speed of sound and vitamin D status. Age-related decline of the calcaneal speed of sound in these men was gradual and biphasic without ethnic difference. Body anthropometry such as height, weight, body mass index, and body fat percentage contributed to the variation of the calcaneal speed of sound in Malaysian men. Age-related changes in testosterone, insulin-like growth factor 1, and thyroid stimulating hormone also influenced the calcaneal speed of sound in these men. This study serves as a reminder that male osteoporosis in Malaysia should be an issue of concern. It is also a basis for a more comprehensive study on bone health in men in the future.
\end{abstract}

Keywords: bone; body mass index; osteopenia; osteoporosis; testosterone; thyroids; vitamin D

\section{Introduction}

Osteoporosis, a metabolic disease of the skeletal system, marked by decreased bone mass and degenerative changes in bone microarchitecture, is the most important cause of bone fragility and fractures in the elderly [1]. Fracture risk in the Asian population is lower compared to the Western population [2]. However, with the rapid expansion of the elderly population in Asia, the incidence of osteoporosis is projected to increase significantly. A representative Japanese study in the Tottori prefecture revealed a 3.3-fold increase in hip fractures for women and 2.3-fold increase for men aged 85 years or above, concurrent with a 3.18-fold increase of lifespan in the population over a period of 20 years (1986-2006) [3]. It is projected that $45 \%$ of the osteoporotic hip fractures will occur in Asia by 2050 , an increase from $26 \%$ in 1990 [4]. Osteoporotic fractures incur significant healthcare and economic burdens. A recent study in the South Korean population indicated that the societal cost of osteoporotic fractures, inclusive of direct and indirect medical costs, increased from USD \$8.8 million in 2007 to $\$ 149.3$ million in 2011 [5]. Another study in the Eastern Saudi Arabian population showed that the treatment cost of osteoporotic fractures of the femur for the first year was USD \$628.95 million, with a projected lifetime cost of $\$ 9.34$ billion in 2025 [6]. The cost estimation of osteoporotic fractures in Malaysia is current unavailable. 
Osteoporosis affects both men and women. A worldwide study of hip fracture incidence in 2000 estimated that $39 \%$ of all osteoporotic fractures occurred in men [7]. Despite a higher prevalence in women, multiple studies have highlighted that men suffer from higher morbidity and mortality after an osteoporotic fracture [8-10]. Pooled data from three longitudinal studies in the United States showed that the six-month mortality rate in men after a hip fracture was $19 \%$ in comparison to $9 \%$ in women [8]. In a separate single-center study conducted in Houston, USA, the 12-month mortality rate was $32 \%$ for male (mean age 80 years) and 17\% female hip fracture patients (mean age 81 years) [11]. In the same study, only $4.5 \%$ of the male fracture patients received any kinds of osteoporotic treatment upon discharge, which was a sharp difference compared to $27 \%$ in female patients [11]. Male fracture patients $(11 \%)$ also had fewer chances of receiving a bone mineral density (BMD) scanning upon follow up compared to female patients (27\%) [11]. This highlights that male osteoporotic patients are underdiagnosed, undertreated and suffering from a lack of monitoring. There is a paucity of similar studies in the Asian region.

Osteoporosis research in Malaysia is very limited. The most comprehensive survey in hip fracture incidence was performed in 1996-1997, whereby Lee and Khir demonstrated that the rate was $218 / 100,000$ for women and $88 / 100,000$ for men [12]. Significant ethnic differences in hip fracture incidence were found, in which it was the highest in the Chinese and lowest in the Indians, for both sexes [12]. Data on the prevalence of osteoporosis, determined based on bone mineral density (BMD) using a dual-energy X-ray absorptiometry (DEXA) technique, was only available in women [13-15]. A study by Lim et al. in middle-aged women (mean age 51 years) living in Kuala Lumpur revealed that 8.6\% of them were osteoporotic based on BMD of the spine and 21.4\% based on BMD of the hip [14]. Osteoporosis research in Malaysia may have been retarded by the limited availability of DEXA devices in the country (two per million citizens) [16]. Furthermore, the DEXA machine is immobile, emits ionizing energy and requires well-trained technicians to handle [17]. A quantitative ultrasound (QUS) device has been used as an alternative in the screening of osteoporosis in Malaysia [17]. Using a QUS device, Hasnah et al. showed that $6 \%$ of the post-menopausal women living in a low-cost housing area in Cheras, Kuala Lumpur were osteoporotic [18]. Chan et al. showed that $55 \%$ of post-menopausal women visited a teaching hospital in Kuala Lumpur had suboptimal bone health based on QUS readings [19]. However, no studies have been conducted on the bone health status in men.

Taking these knowledge gaps into consideration, bone health in Malaysian men was established as an important component of the Malaysian Aging Men Study (MAMS). The bone chapter in MAMS aimed to determine the bone health of Chinese and Malay men aged 20 years and above living in Kuala Lumpur using a calcaneal ultrasonometer. The associations between bone health indicated by calcaneal speed of sound and demographic, body anthropometric, physical activity-associated, and endocrinological factors in Malaysian men were examined. This review aimed to provide a concise summary of the findings in the bone chapter of MAMS.

\section{Study Design}

The MAMS was a cross-sectional study performed between September 2009 and December 2012. Subjects recruited were Chinese and Malay men aged 20 years and above living in Kuala Lumpur, Malaysia and its environs. They were solicited via advertisements in national newspapers, radio broadcasts, flyers, and announcements at community centers and religious venues. Inclusion and exclusion criteria of the study were stated clearly in the advertisements. Subjects with pre-existing medical conditions affecting their bone health, such as osteogenesis imperfecta, rickets, hypogonadism, hyper/hypocalcaemia, and hyper/hypoparathyroidism were excluded. Subjects receiving anabolic steroids, osteoporosis treatment, thiazides, diuretics, glucocorticoids, anticonvulsants, and lithium were also omitted. Subjects included could walk without assistance and did not suffer any fractures six months prior to the screening session. Qualified physicians performed physical examinations and medical histories of the subjects during the screening session. The study was explained to the subjects thoroughly before they gave written informed consent to participate. The Universiti Kebangsaan 
Malaysia Medical Centre Research Ethics Committee reviewed and approved the study protocol (Code: UKM-AP-TKP-09-2009).

Subjects answered a basic self-administered demographic questionnaire. Physical activity status of the subjects was assessed using the International Physical Activity Questionnaire (IPAQ). Body anthropometry of the subjects, including body weight, body mass index, and body fat percentage, was measured using a body composition analyzer. Bone health of the subjects was measured using a calcaneal quantitative ultrasonometer as per the recommendation of International Society of Clinical Densitometry [20]. The index of bone health generated by the machine was speed of sound (SOS). The average of three SOS readings was used for analysis to ensure consistency. The short-term in vivo coefficient of variation for this device was $2.9 \%$. Fasting blood of the subjects was collected in the morning on the day of the screening session. Testosterone, estradiol, free triiodothyronine (T3), free thyroxine (T4), and thyroid stimulating hormone (TSH) were tested using an automated competitive immunoassay analyzer with direct chemiluminescence. Calcium and phosphate levels were tested using an automated colorimetric analyzer. Intact parathyroid hormone (PTH), insulin-like growth factor-1 (IGF1), 25-dihydroxyvitamin D (25(OH)D), and sex hormone-binding globulin (SHBG) were tested using enzyme-linked immunosorbent assay kits. Free and bioavailable testosterone and estradiol levels were calculated based on Sodergard's formula [21].

\section{The Prevalence of Suboptimal Bone Health Indicated by Calcaneal SOS in Malaysian Men}

A quantitative ultrasound device is not a diagnostic tool for osteoporosis. Thus, diagnostic criteria established by the World Health Organization (WHO) based on DEXA might not be suitable for QUS [22]. Despite this, Kishimoto et al. had established the T-score equivalent for the QUS device used in this study, CM series, which was comparable to T-scores generated by DEXA [23]. According to their studies, a patient with a SOS T-score of -1.12 or greater was considered as normal; a SOS T-score between -1.80 and -1.12 was considered as having osteopenia; and a SOS T-score of -1.80 or lower was considered as having osteoporosis [23]. This set of cut-off values was specific to QUS device of the $\mathrm{CM}$ series; thus, it is not applicable to other devices.

Based on the reference values provided by the manufacturer, $3.7 \%$ of the 818 subjects screened were osteoporotic and $19.9 \%$ were osteopenic [24]. However, bone density values differ significantly by populations and the reference values used in the $\mathrm{CM}$ series were established in the Japanese population. Therefore, we compared the SOS values of the study population with the reference values provided by the manufacturer according to age groups (10 year intervals). Mean SOS values of the local population were found to be significantly higher compared to the Japanese reference, particularly after the age of 40 years [24]. Thus, we recalculated the T-score based on local reference value (mean SOS values of young men aged 20-29 years) and the prevalence of osteoporosis changed to $2.6 \%$ and osteopenia $21.3 \%[24]$.

The prevalence of osteoporosis generated using QUS in the current study was comparable to other studies using DEXA. A systematic review of 91 studies on osteoporosis in 51,906 Chinese men aged 20 years and above showed that the prevalence of osteoporosis was $3.2 \%$ based on lumbar spine BMD and 5.3\% based on femoral neck BMD [25]. The prevalence of osteoporosis for Chinese men in Hong Kong aged 50 years and above was $6 \%$ based on hip BMD and $7 \%$ based on lumbar spine BMD. In Taiwan, the prevalence of male osteoporosis was $1.6 \%$ according to national health insurance records between 1999 and 2001 [26,27]. A survey in Thailand revealed that the prevalence of osteoporosis in men aged 20 years and above was $12.6 \%$ based on lumbar spine BMD and $4.6 \%$ based on femoral neck BMD [28].

\section{The Relationship between Age and Calcaneal SOS}

Calcaneal SOS of Malaysian men showed a gradual but significant decline starting at the age of 30 years, followed by a steeper decline after the age of 60 years (Figure 1). The age trend of SOS in this study was similar to the findings of Liu et al. in mainland Chinese men, characterized by a drastic drop 
in SOS values from the 20-29 year age group to the 30-39 year age group. This decrease was also the most significant decrease in SOS per decade in their study [29]. The deterioration of bone heath with age was reflected in the exponential increase in hip fracture incidence in Malaysian men in their later life [12]. The exact reason for a steep decrease of bone health in men in their thirties remained unclear at this moment. A study by Riggs et al. assessing bone health in men using peripheral quantitative computed tomography (pQCT) suggested the biphasic age-related bone loss in men was due to trabecular bone loss that began before midlife, and cortical bone loss that occurred after midlife [30]. Similar age-related patterns of bone loss were not observed in other studies. A large bone health study performed in seven Asian countries using quantitative ultrasound revealed a gradual and uniform decline of the stiffness index value with the age in men [31].

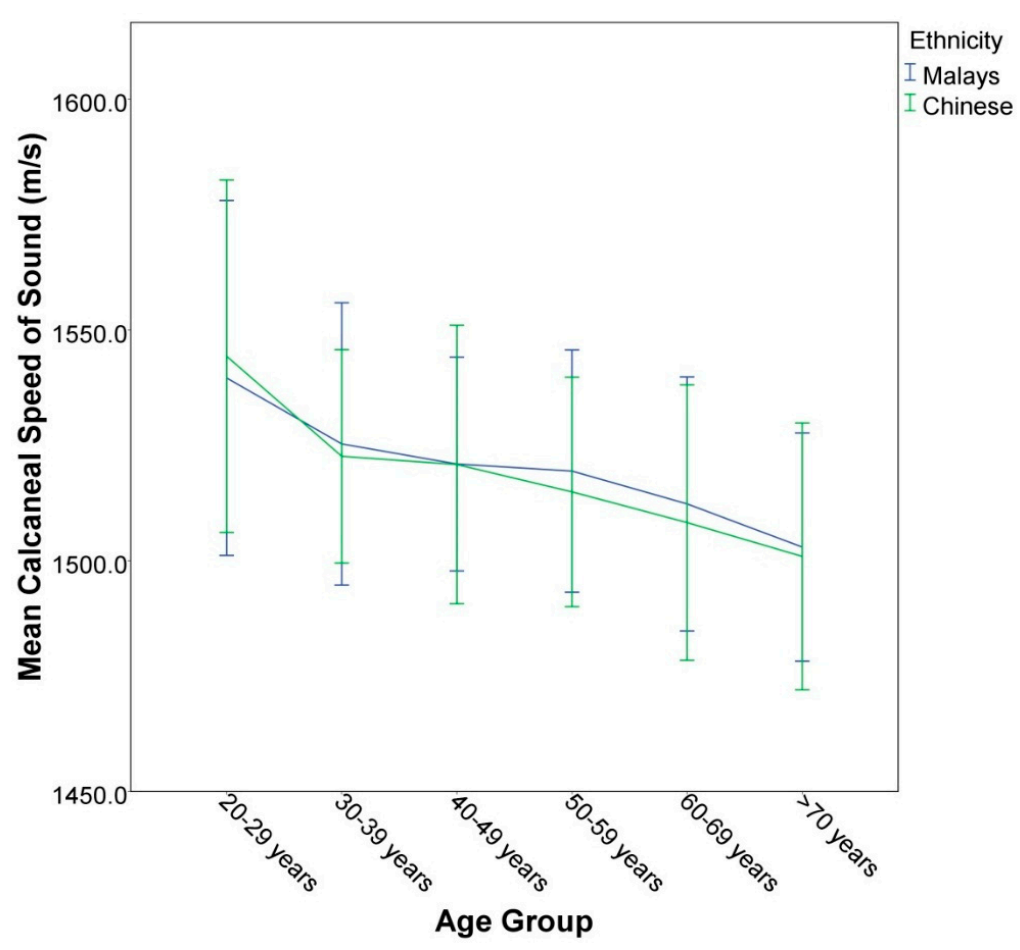

Figure 1. The age-trend of SOS between Chinese and Malay men in Malaysia.

\section{The Relationship between Ethnicity and Calcaneal SOS}

Ethnic difference in bone health was observed in the United States. The bone mineral content (BMC) and BMD values determined using DEXA were the highest in African Americans, followed by Hispanics and non-Hispanic Caucasians according to the third National Health and Nutrition Survey [32]. The Baltimore Men's Osteoporosis Study also indicated that the age-related decline in femoral BMD, total hip bone mineral apparent density (BMAD), and prevalence of vertebral fractures were lower in African Americans compared to their White counterparts [33,34]. In Malaysia and Singapore, the incidence of hip fractures in men aged 50 years and above was the highest among the Chinese, followed by the Indians and the Malays [12,35]. In contrast, our study showed that the SOS value was lower in Chinese compared to Malay men, but it was not statistically significant [24] (Figure 1). Thus, variation in SOS value alone did not explain the higher fracture rate among the Chinese population in Malaysia.

\section{The Relationship between Body Anthropometry and Calcaneal SOS}

Body weight, height, bone mass index (BMI), and body fat percentage were associated with the SOS values in the subjects of this study even after adjustment for age [36]. After classifying subjects into their 
respective BMI categories [37], we observed that obese subjects (BMI $>30 \mathrm{~kg} \cdot \mathrm{m}^{-2}$ ) had significantly higher SOS value compared to subjects with normal BMI $\left(18.5 \mathrm{~kg} \cdot \mathrm{m}^{-2} \leqslant \mathrm{BMI}<25 \mathrm{~kg} \cdot \mathrm{m}^{-2}\right)$ and overweight subjects $\left(25 \mathrm{~kg} \cdot \mathrm{m}^{-2} \leqslant \mathrm{BMI}<30 \mathrm{~kg} \cdot \mathrm{m}^{-2}\right)$ [36]. Based on waist circumference categories [38], there was no significant difference in SOS values between subjects with $(\geqslant 90 \mathrm{~cm})$ and without central obesity $(<90 \mathrm{~cm})$ [36]. There was also no significant difference in SOS values between subjects in different classes of body fat percentages measured using bioelectrical impedance method [36]. Interestingly, stepwise regression analysis revealed that height, weight, and body fat were significant predictors of SOS in Malaysian men after adjustment for age and physical activity status [36]. Calcaneal SOS value was negatively associated with height and body fat percentage, and positively associated with body weight in the regression model [36]. In the case of body fat percentage, our results showed that conventional method of classification might be inappropriate for the prediction of bone health status.

The relationship between body anthropometry and bone health is intriguing. The negative association between height and bone health found in this study has been observed by others. Previous epidemiological studies demonstrated that taller individuals had higher risk of fractures $[39,40]$. Bjørnerem et al., using high-resolution pQCT, demonstrated that taller women possessed wider bones with thinner and more porous cortices [41]. This provides an explanation for the negative association between height and SOS values as observed in this study, pending validation in men. Higher body weight and BMI had been shown to protect bone health, presumably by acting as a mechanical load to stimulate an increase in bone mass [42]. Body mass index reflects body size, but it does not give an accurate depiction of obesity $[43,44]$. The negative relationship between body fat percentage and SOS value indicated that obesity could exert negative effects on bone. Obesity is often associated with increased circulating inflammatory cytokines due to chronic inflammation $[45,46]$. These cytokines suppress osteoblast differentiation and promote the formation of osteoclasts [47,48]. Increased proliferation of adipocytes may compete with the formation of osteoblasts since both of them originate from mesenchymal stem cells [49]. These adipogenic factors could lead to reduced bone formation and increased bone resorption, resulting in a net bone loss.

\section{The Relationship between Physical Activity and Calcaneal SOS}

Based on the assessment by IPAQ, subjects were classified into having low, moderate, or high physical activity level. Subjects having low physical activity level had significantly lower calcaneal SOS value compared to subjects having moderate or high physical activity level [36]. Previous studies demonstrated that physical activity was associated with improved BMD assessed by DEXA and bone strength by pQCT in men [50,51]. In a study by Blanchet et al., leisure physical activity was associated with calcaneal QUS indices but not BMD of the lumbar spine in a group of post-menopausal women [52].

The calcaneus is the weight-bearing bone experiencing maximal ground reaction force during physical activity [53]. Significant adaption would be expected from the skeletal deformation and straining at this site, which serves as osteogenic stimuli promoting bone growth. Bone is more responsive to weight-bearing physical activity [54]. However, the use of IPAQ represented a limitation in the current study because it did not differentiate between weight-bearing and non-weight-bearing physical activity.

\section{The Relationship between Sex Hormones and Calcaneal SOS}

Men do not experience a rapid decline of sex hormone similar to women in their midlife. The decline of testosterone is gradual and clinical testosterone deficiency is not universal in elderly men [55]. The decline of testosterone is contributed by two mechanisms. Firstly, the capacity of Leydig's cells in the testes to synthesize testosterone in response to luteinizing hormone decreases with age [56,57]. Secondly, the increased SHBG production by the liver with age significantly limits the bioavailability of testosterone [58]. The combined effects of these two factors lead to age-related testosterone deficiency syndrome and imposes negative impacts on bone health. 
Testosterone exerts direct and indirect effects on the bone. Bone cells are equipped with androgen receptors to respond directly to androgenic stimulation. Testosterone can also be aromatized in the bone or by peripheral tissues to estrogen and acts on bone cells through estrogen receptors [59,60]. A study by Falahati-Nini et al. showed that both testosterone and estrogen contributed to bone formation in elderly men, but only estrogen contributed significantly to suppression of bone resorption [61].

Our study showed that total, bioavailable and free testosterone levels started to decline in men in their fifties. The declines of bioavailable and free testosterone were steeper compared to total testosterone. This contributed to the increase of SHBG levels, beginning in their fifties [62]. There was no specific age-trend for total, bioavailable, and free estradiol levels in Malaysian men. However, subgroup analysis based on ethnicity revealed an interesting age-related trend between Chinese and Malay men. The estradiol levels of Chinese men increased until they were in their fifties and decreased thereafter, while the estradiol levels in Malay men showed a consistent decrease with age [62] (Figure 2). The reason for this difference in trend is still unclear at this moment. Overall, there was no significant difference in sex hormone levels between Chinese and Malay men [62]. This observation was different from studies conducted in the United States. Rohrmann et al. demonstrated that estradiol levels were higher in African Americans compared to non-Hispanic White men, but no difference was seen in testosterone levels [31]. However, Winters et al. observed that testosterone levels were higher in African Americans compared to non-Hispanic White men [63].
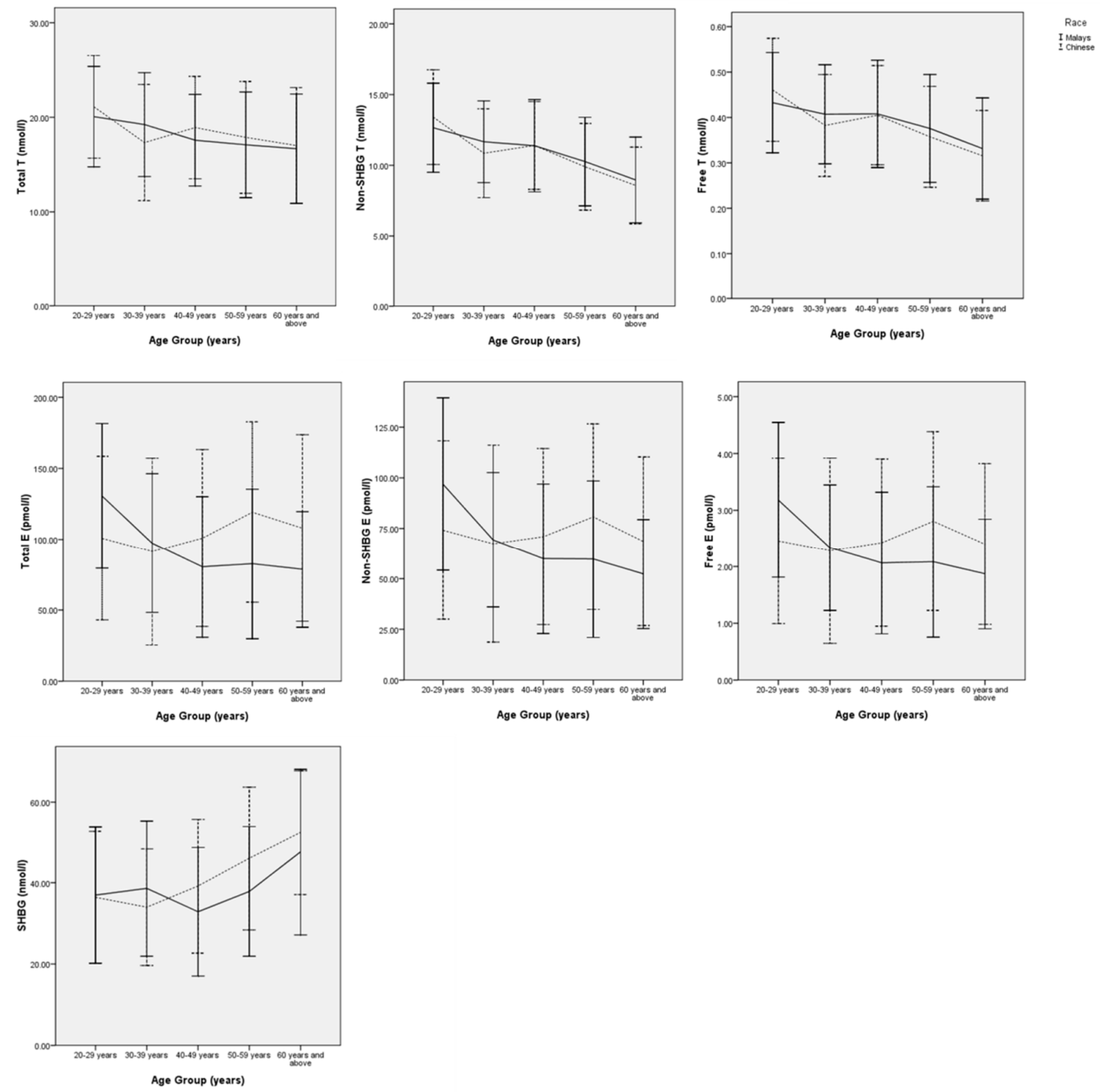

Age Group (years)

Figure 2. The age-trend of sex hormones between Chinese and Malay men in Malaysia [62]. 
Using multiple regression models, we showed that total, bioavailable, and free testosterone and SHBG levels were significant predictors of calcaneal SOS in Malaysian men [64,65]. Higher testosterone levels were associated with a higher SOS value in men, while higher SHBG levels predicted a lower SOS value [64,65]. No associations between SOS value and estradiol levels were found [64]. Many epidemiological studies have uncovered a positive relationship between testosterone and bone health assessed by DEXA and QUS [66-70]. However, there were other studies supporting that estrogen was more influential in bone health in men compared to testosterone. In the Rochester Epidemiology Study, Khosla et al. showed that estrogen was the only significant predictor of proximal femoral BMD after adjustment for confounders [71]. Arauja et al. revealed that only estradiol levels correlated with BMD at the femoral neck, hip, ultradistal radius, and spine, after adjustment for confounders but testosterone did not [72]. We postulated two reasons for the discrepancies between the current study and the previous ones. Firstly, Kuchuk et al. demonstrated that broadband attenuation of sound (BUA) was associated with estradiol levels in men, while SOS was associated with testosterone levels [66]. Since BUA and SOS could reflect different properties of bone [73], this indicated that estradiol could have an impact on aspects of bone quality that was undetected by SOS [60]. Secondly, phytoestrogen intake was high among the Asians [74]. This could have desensitized the bone in our subjects to the effects of estrogen.

\section{The Relationship between Calcium Homeostasis and Calcaneal SOS}

The 25-hydroxyvitamin $\mathrm{D}(25(\mathrm{OH}) \mathrm{D})$ is a prohormone synthesized cutaneously when we are exposed to ultraviolet $\mathrm{B}$ in the sunlight. Its deficiency leads to increased parathyroid hormone, which mobilizes the calcium reserve in our bone to the circulation, thus causing osteoporosis [75]. Vitamin D status could be divided into normal, insufficiency (30 nmol/L $\leqslant$ Vitamin $\mathrm{D}<50 \mathrm{nmol} / \mathrm{L}$ ), and deficiency $(<30 \mathrm{nmol} / \mathrm{L})$ based on the recommendation of the Institute of Medicine, USA [76]. A surprisingly large proportion of population in the tropical countries and in the sub-Sahara regions were found to possess suboptimal vitamin D level [77-80]. In our study, $22.7 \%$ of the subjects had vitamin D insufficiency and $0.5 \%$ had vitamin D deficiency [81] (Figure 3). Vitamin D insufficiency and deficiency were more prevalent among the Malay men compared to their Chinese counterparts probably due to their darker complexion [81]. Melanin competes with vitamin D synthesizing enzymes in our skin to absorb sunlight, thus hampering vitamin D production [82]. This observation was similar to a small-scale study performed in Singapore, in which 30\% of the Chinese men and $48 \%$ of the Malay men had vitamin D insufficiency [83]. A study by Forrest and Stuhldreher demonstrated that vitamin D level was the lowest in African American, followed by Hispanic and non-Hispanic Whites [84]. Subjects with higher BMI had lower 25(OH)D level because vitamin D is sequestered in adipose tissue [81]. Vitamin D deficiency could also lead to metabolic syndrome, with central obesity being one of the key features [85]. Thus, the relationship between vitamin $\mathrm{D}$ and obesity could be two-way. The $25(\mathrm{OH}) \mathrm{D}$ level was lower in younger subjects probably due to the tendency to work indoor and the use of sunscreens [81].
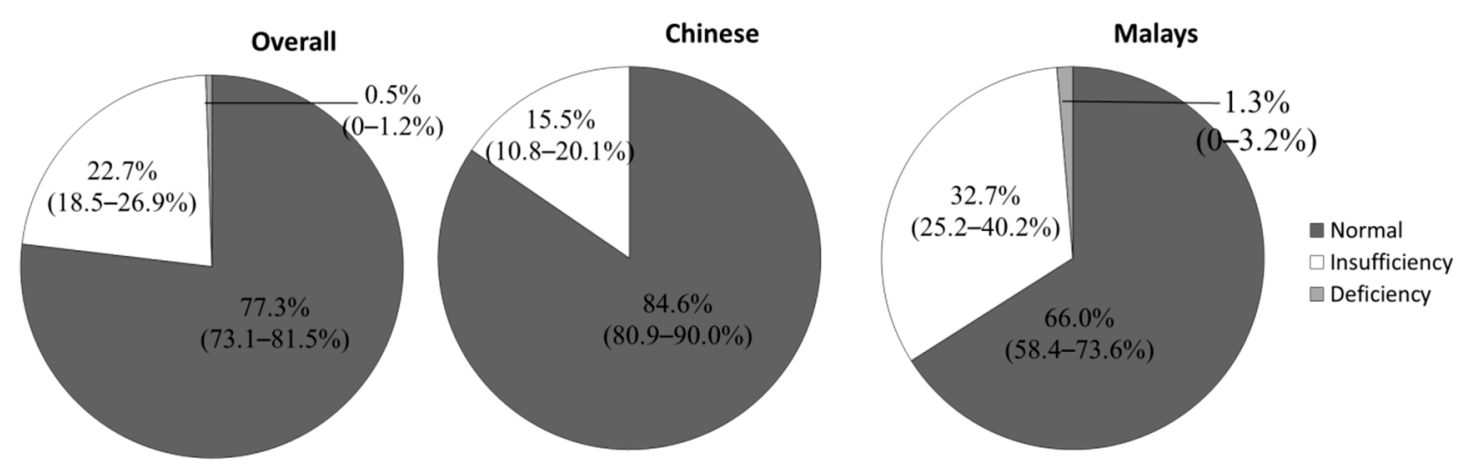

Figure 3. Vitamin status of Malaysian men. 
There was a significant negative association between 25(OH)D and PTH level, but not serum calcium and inorganic phosphate levels in the subjects [24]. Serum $25(\mathrm{OH}) \mathrm{D}, \mathrm{PTH}$, calcium, and inorganic phosphate levels also did not predict SOS values in the subjects [28]. The problem of suboptimal vitamin D levels in our subjects was not serious; hence, it did not have a significant impact on their bone health. On the other hand, increased vitamin D levels might not translate to a linear increase in SOS value; thus a significant relationship was not observed.

\section{The Relationship between Thyroid Hormones and Calcaneal SOS}

The negative effects of overt hyperthyroidism on bone health were well established, but less information is available for the euthyroids [86]. Our study showed that thyroid stimulating hormone (TSH) was positively associated with SOS values in euthyroid men, but free T3 and T4 hormones were not [87]. Kim et al. showed that a higher TSH level was associated with a higher BMD at the lumbar spine in Korean men and a lower risk of osteoporosis in Korean women [88,89]. Similar findings were observed in the Tromso Study and the third National Health and Nutrition Examination Survey of the USA [90,91]. Receptors for TSH (TSHR) had been discovered in bone cells and TSH-influenced pathways involved in osteoclastogenesis (JNK/c-jun and NFKB) and osteoblastogenesis (LRP5, Flk-1 and Wnt5a) [92-95]. The effects of TSH on bone were independent of T3 and T4 levels, as evidenced by the severe osteoporosis found in TSHR knockout mice supplemented with thyroid hormones [93]. These provide the possible molecular mechanisms behind the effects of TSH on bone health.

\section{The Relationship between Insulin-Like Growth Factor 1 and Calcaneal SOS}

Insulin-like growth factor 1 (IGF1) is traditionally linked to regulation of growth hormone [96]. In our study, IGF1 was positively associated with SOS value in Malaysian men [87]. This finding was in accordance with several previous studies $[97,98]$. However, other studies found that the effects of IGF1 was more profound in women but not in men $[99,100]$. In vitro studies demonstrated that IGF1 influenced osteoblast migration, matrix synthesis, and mineralization [101-103]. Mice with IGF1 knockout osteoblast showed decreased bone structural, dynamic, and static histomorphometric indices [103].

\section{Limitations}

The study was cross-sectional in nature; thus, causality could not be inferred. We also used a non-randomized sampling technique; hence, generalization of the results should be performed with caution. Indians, who represent the third-largest ethnic group in Malaysia, were not recruited in the study due to logistic difficulties. However, Chinese and Malay men together represent more than $92 \%$ of the total male population in Malaysia. The QUS device used, CM-200 (Furuno Electric, Nishinomiya, Japan), only generated SOS as the bone health determinant. Another index, BUA, was not generated. Despite this, previous studies had established that SOS was closely related to BMD [104-106]. A meta-analysis also revealed that one standard deviation change in SOS increased the relative risk for fracture to 1.96 (CI: 1.64-2.34) [107]. The calcaneal bone was examined, but other bone segments more prone to fracture were not due to the limitation of the QUS device. This was done as per the recommendation of International Society of Clinical Densitometry [20]. Dual-energy X-ray absorptiometry was not used to assess the BMD of the subject because the device was not available to us at the time of the study. Other aspects of bone health, such as fracture risk assessments, were not performed on the subjects. Other factors influencing bone health, such as nutritional status, the use of supplements, and caffeine intake, were not taken into account in this study. Nevertheless, this study was the first study attempting to quantify the bone health status in Malaysian men and the findings were useful in planning more comprehensive studies in the future. 


\section{Conclusions}

A significant proportion of the Malaysian men has suboptimal bone health indicated by calcaneal SOS and vitamin D status. Age-related decline of calcaneal SOS in Malaysian men is a multifactorial problem. It is associated with changes in hormonal factors, particularly testosterone, body anthropometry, physical activity status, and other factors yet to be discovered (Figure 4). Preventive measures should be considered to retard the progress of osteoporosis in Malaysian men so that their quality of life will not be affected by this disease. These measures may be in the form of regular screening, lifestyle changes, and hormonal or nutritional supplements. However, further studies are required to determine the appropriate preventive approach.

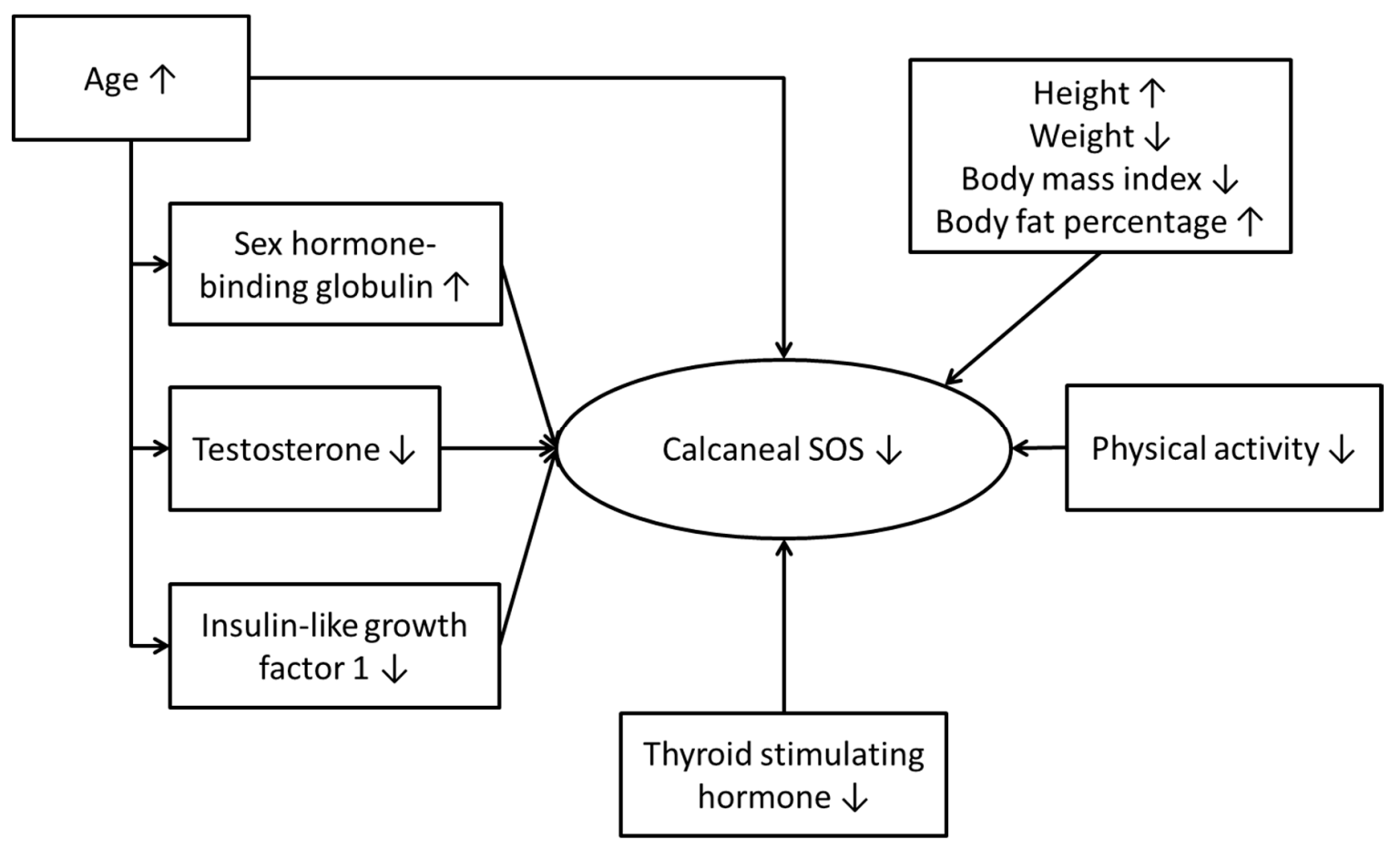

Figure 4. Factors influencing calcaneal SOS in Malaysian men.

Acknowledgments: This work is supported by Universiti Kebangsaan Malaysia via GGPM-2015-036 and DIP-2014-040 grants.

Author Contributions: Kok-Yong Chin drafted the manuscript. Wan Zurinah Wan Ngah was principal investigator of Malaysian Aging Men Study (MAMS). Soelaiman Ima-Nirwana was the co-investigator for Bone Chapter of MAMS and provided the final approval for the manuscript.

Conflicts of Interest: The authors declare no conflict of interest.

\section{References}

1. Edwards, M.H.; Dennison, E.M.; Aihie Sayer, A.; Fielding, R.; Cooper, C. Osteoporosis and sarcopenia in older age. Bone 2015, 80, 126-130. [CrossRef] [PubMed]

2. Kanis, J.A.; Oden, A.; McCloskey, E.V.; Johansson, H.; Wahl, D.A.; Cooper, C. A systematic review of hip fracture incidence and probability of fracture worldwide. Osteoporos. Int. 2012, 23, 2239-2256. [CrossRef] [PubMed]

3. Hagino, H.; Furukawa, K.; Fujiwara, S.; Okano, T.; Katagiri, H.; Yamamoto, K.; Teshima, R. Recent trends in the incidence and lifetime risk of hip fracture in Tottori, Japan. Osteoporos. Int. 2008, 20, 543-548. [CrossRef] [PubMed]

4. Gullberg, B.; Johnell, O.; Kanis, J.A. World-wide projections for hip fracture. Osteoporos. Int. 1997, 7, 407-413. [CrossRef] [PubMed] 
5. Kim, J.; Lee, E.; Kim, S.; Lee, T.J. Economic burden of osteoporotic fracture of the elderly in South Korea: A national survey. Value Health 2016, 9, 36-41. [CrossRef]

6. Sadat-Ali, M.; Al-Dakheel, D.A.; Azam, M.Q.; Al-Bluwi, M.T.; Al-Farhan, M.F.; AlAmer, H.A.; Al-Meer, Z.; Al-Mohimeed, A.; Tabash, I.K.; Karry, M.O.; et al. Reassessment of osteoporosis-related femoral fractures and economic burden in Saudi Arabia. Arch. Osteoporos. 2015, 10, 37. [CrossRef] [PubMed]

7. Johnell, O.; Kanis, J.A. An estimate of the worldwide prevalence and disability associated with osteoporotic fractures. Osteoporos. Int. 2006, 17, 1726-1733. [CrossRef] [PubMed]

8. Penrod, J.D.; Litke, A.; Hawkes, W.G.; Magaziner, J.; Doucette, J.T.; Koval, K.J.; Silberzweig, S.B.; Egol, K.A.; Siu, A.L. The association of race, gender, and comorbidity with mortality and function after hip fracture. J. Gerontol. A Biol. Sci. Med. Sci. 2008, 63, 867-872. [CrossRef] [PubMed]

9. Endo, Y.; Aharonoff, G.B.; Zuckerman, J.D.; Egol, K.A.; Koval, K.J. Gender differences in patients with hip fracture: A greater risk of morbidity and mortality in men. J. Orthop. Trauma 2005, 19, 29-35. [CrossRef] [PubMed]

10. Holt, G.; Smith, R.; Duncan, K.; Hutchison, J.D.; Gregori, A. Gender differences in epidemiology and outcome after hip fracture: Evidence from the Scottish hip fracture audit. Bone Joint J. 2008, 90, 480-483. [CrossRef] [PubMed]

11. Kiebzak, G.M.; Beinart, G.A.; Perser, K.; Ambrose, C.G.; Siff, S.J.; Heggeness, M.H. Undertreatment of osteoporosis in men with hip fracture. Arch. Intern. Med. 2002, 162, 2217-2222. [CrossRef] [PubMed]

12. Lee, J.-K.; Khir, A.S.M. The incidence of hip fracture in Malaysians above 50 years of age: Variation in different ethnic groups. APLAR J. Rheumatol. 2007, 10, 300-305. [CrossRef]

13. Damodaran, P.; Subramaniam, R.; Omar, S.Z.; Nadkarni, P.; Paramsothy, M. Profile of a menopause clinic in an urban population in Malaysia. Singap. Med. J. 2000, 41, 431-435.

14. Lim, P.S.; Ong, F.B.; Adeeb, N.; Seri, S.S.; Noor-Aini, M.Y.; Shamsuddin, K.; Hapizah, N.; Mohamed, A.L.; Mokhtar, A.; Wan, H.W. Bone health in urban midlife Malaysian women: Risk factors and prevention. Osteoporos. Int. 2005, 16, 2069-2079. [CrossRef] [PubMed]

15. Zaini, W.M.; Md Ariff, A. Bone mineral density assessment in pre- and postmenopausal women: Comparison between t-scores by heel QUS and DXA in HRPZII. Med. J. Malays. 2012, 67, 487-490.

16. Mithal, A.; Ebeling, P. The Asia-Pacific Regional Audit: Epidemiology, Costs E Burden of Osteoporosis in 2013; International Osteoporosis Foundation: Nyon, Switzerland, 2013.

17. Chin, K.-Y.; Ima-Nirwana, S. Calcaneal quantitative ultrasound as a determinant of bone health status: What properties of bone does it reflect? Int. J. Med. Sci. 2013, 10, 1778-1783. [CrossRef] [PubMed]

18. Hasnah, H.; Amin, I.; Suzana, S. Bone health status and lipid profile among post-menopausal Malay women in Cheras, Kuala Lumpur. Malays. J. Nutr. 2012, 18, 161-171. [PubMed]

19. Chan, P.J.; Nurul, Z.Z.; Chuah, J.S.; Nabil, M.M.A.; Isa, N.M.; Sabarul, A.M.; Nazrun, A.S. Association between risk factors of osteoporosis and bone mineral density in women of different ethnic groups in a Malaysian hospital. Int. J. Osteoporos. Metab. Disord. 2014, 7, 1-11.

20. Krieg, M.A.; Barkmann, R.; Gonnelli, S.; Stewart, A.; Bauer, D.C.; Del Rio Barquero, L.; Kaufman, J.J.; Lorenc, R.; Miller, P.D.; Olszynski, W.P.; et al. Quantitative ultrasound in the management of osteoporosis: The 2007 ISCD official positions. J. Clin. Densitom. 2008, 11, 163-187. [CrossRef] [PubMed]

21. Sodergard, R.; Backstrom, T.; Shanbhag, V.; Carstensen, H. Calculation of free and bound fractions of testosterone and estradiol-17 beta to human plasma proteins at body temperature. J. Steroid Biochem. 1982, 16, 801-810. [CrossRef]

22. Frost, M.L.; Blake, G.M.; Fogelman, I. Can the who criteria for diagnosing osteoporosis be applied to calcaneal quantitative ultrasound? Osteoporos. Int. 2000, 11, 321-330. [CrossRef] [PubMed]

23. Kishimoto, H.; Yoh, K.; Ohta, H.; Gorai, I.; Hashimoto, J.; Nakatsuka, K.; Yoshimoto, Y.; Makita, K. Normative data and cut-off values determined using quantitative ultrasound CM-100 in Japanese women. Osteoporos. Jpn. 2003, 11, 129-132.

24. Chin, K.-Y.; Soelaiman, I.-N.; Mohamed, I.N.; Mohamed, N.; Shuid, A.N.; Muhammad, N.; Wan Ngah, W.Z. Discrepancy between the quantitative ultrasound value of Malaysian men and the manufacturer's reference and the impact on classification of bone health status. J. Clin. Densitom. 2013, 16, 189-195. [CrossRef] [PubMed]

25. Zhang, Z.-Q.; Ho, S.C.; Chen, Z.-Q.; Zhang, C.-X.; Chen, Y.-M. Reference values of bone mineral density and prevalence of osteoporosis in Chinese adults. Osteoporos. Int. 2013, 25, 497-507. [CrossRef] [PubMed] 
26. Wang, Y.; Tao, Y.; Hyman, M.E.; Li, J.; Chen, Y. Osteoporosis in China. Osteoporos. Int. 2009, 20, $1651-1662$. [CrossRef] [PubMed]

27. Lynn, H.S.; Lau, E.M.; Au, B.; Leung, P.C. Bone mineral density reference norms for Hong Kong Chinese. Osteoporos. Int. 2005, 16, 1663-1668. [CrossRef] [PubMed]

28. Pongchaiyakul, C.; Apinyanurag, C.; Soontrapa, S.; Soontrapa, S.; Pongchaiyakul, C.; Nguyen, T.V.; Rajatanavin, R. Prevalence of osteoporosis in Thai men. J. Med. Assoc. Thail. 2006, 89, 160-169.

29. Liu, W.; Xu, C.-L.; Zhu, Z.-Q.; Wang, W.; Han, S.-M.; Zu, S.-Y.; Zhu, G.-J. Characteristics of calcaneus quantitative ultrasound normative data in Chinese mainland men and women. Osteoporos. Int. 2006, 17, 1216-1224. [CrossRef] [PubMed]

30. Riggs, B.L.; Melton, L.J.; Robb, R.A.; Camp, J.J.; Atkinson, E.J.; McDaniel, L.; Amin, S.; Rouleau, P.A.; Khosla, S. A population-based assessment of rates of bone loss at multiple skeletal sites: Evidence for substantial trabecular bone loss in young adult women and men. J. Bone Min. Res. 2008, 23, 205-214. [CrossRef] [PubMed]

31. Rohrmann, S.; Nelson, W.G.; Rifai, N.; Brown, T.R.; Dobs, A.; Kanarek, N.; Yager, J.D.; Platz, E.A. Serum estrogen, but not testosterone, levels differ between black and white men in a nationally representative sample of Americans. J. Clin. Endocrinol. Metab. 2007, 92, 2519-2525. [CrossRef] [PubMed]

32. Araujo, A.B.; Travison, T.G.; Harris, S.S.; Holick, M.F.; Turner, A.K.; McKinlay, J.B. Race/ethnic differences in bone mineral density in men. Osteoporos. Int. 2007, 18, 943-953. [CrossRef] [PubMed]

33. Tracy, J.K.; Meyer, W.A.; Grigoryan, M.; Fan, B.; Flores, R.H.; Genant, H.K.; Resnik, C.; Hochberg, M.C. Racial differences in the prevalence of vertebral fractures in older men: The Baltimore men's osteoporosis study. Osteoporos. Int. 2006, 17, 99-104. [CrossRef] [PubMed]

34. Tracy, J.K.; Meyer, W.A.; Flores, R.H.; Wilson, P.D.; Hochberg, M.C. Racial differences in rate of decline in bone mass in older men: The Baltimore men's osteoporosis study. J. Bone Min. Res. 2005, 20, 1228-1234. [CrossRef] [PubMed]

35. Lau, E.M.; Lee, J.K.; Suriwongpaisal, P.; Saw, S.M.; Das De, S.; Khir, A.; Sambrook, P. The incidence of hip fracture in four Asian countries: The Asian osteoporosis study (AOS). Osteoporos. Int. 2001, 12, 239-243. [CrossRef] [PubMed]

36. Chin, K.-Y.; Soelaiman, I.-N.; Mohamed, I.N.; Ibrahim, S.; Ngah, W.Z.W. The effects of age, physical activity level, and body anthropometry on calcaneal speed of sound value in men. Arch. Osteoporos. 2012, 7, 135-145. [CrossRef] [PubMed]

37. World Health Organization. Obesity: Preventing and Managing the Global Epidemic: Report of a Who Consultation; World Health Organization: Geneva, Switzerland, 2000.

38. Moy, F.M.; Atiya, A.S. Waist circumference as a screening tool for weight management: Evaluation using receiver operating characteristic curves for Malay subjects. Asia Pac. J. Public Health 2003, 15, 99-104. [CrossRef] [PubMed]

39. Hemenway, D.; Feskanich, D.; Colditz, G.A. Body height and hip fracture: A cohort study of 90,000 women. Int. J. Epidemiol. 1995, 24, 783-786. [CrossRef] [PubMed]

40. Joakimsen, R.M.; Fonnebo, V.; Magnus, J.H.; Tollan, A.; Sogaard, A.J. The Tromso study: Body height, body mass index and fractures. Osteoporos. Int. 1998, 8, 436-442. [CrossRef] [PubMed]

41. Bjornerem, A.; Bui, Q.M.; Ghasem-Zadeh, A.; Hopper, J.L.; Zebaze, R.; Seeman, E. Fracture risk and height: An association partly accounted for by cortical porosity of relatively thinner cortices. J. Bone Min. Res. 2013, 28, 2017-2026. [CrossRef] [PubMed]

42. De Laet, C.; Kanis, J.A.; Oden, A.; Johanson, H.; Johnell, O.; Delmas, P.; Eisman, J.A.; Kroger, H.; Fujiwara, S.; Garnero, P.; et al. Body mass index as a predictor of fracture risk: A meta-analysis. Osteoporos. Int. 2005, 16, 1330-1338. [CrossRef] [PubMed]

43. Romero-Corral, A.; Somers, V.K.; Sierra-Johnson, J.; Thomas, R.J.; Collazo-Clavell, M.L.; Korinek, J.; Allison, T.G.; Batsis, J.A.; Sert-Kuniyoshi, F.H.; Lopez-Jimenez, F. Accuracy of body mass index in diagnosing obesity in the adult general population. Int. J. Obes. (Lond.) 2008, 32, 959-966. [CrossRef] [PubMed]

44. Yoon, J.L.; Cho, J.J.; Park, K.M.; Noh, H.M.; Park, Y.S. Diagnostic performance of body mass index using the western pacific regional office of world health organization reference standards for body fat percentage. J. Korean Med. Sci. 2015, 30, 162-166. [CrossRef] [PubMed] 
45. Panagiotakos, D.B.; Pitsavos, C.; Yannakoulia, M.; Chrysohoou, C.; Stefanadis, C. The implication of obesity and central fat on markers of chronic inflammation: The Attica study. Atherosclerosis 2005, 183, 308-315. [CrossRef] [PubMed]

46. Festa, A.; D'Agostino, R., Jr.; Williams, K.; Karter, A.J.; Mayer-Davis, E.J.; Tracy, R.P.; Haffner, S.M. The relation of body fat mass and distribution to markers of chronic inflammation. Int. J. Obes. 2001, 25, 1407-1415. [CrossRef] [PubMed]

47. Ding, J.; Ghali, O.; Lencel, P.; Broux, O.; Chauveau, C.; Devedjian, J.C.; Hardouin, P.; Magne, D. TNF-alpha and IL-1beta inhibit RUNX2 and collagen expression but increase alkaline phosphatase activity and mineralization in human mesenchymal stem cells. Life Sci. 2009, 84, 499-504. [CrossRef] [PubMed]

48. Kudo, O.; Sabokbar, A.; Pocock, A.; Itonaga, I.; Fujikawa, Y.; Athanasou, N.A. Interleukin-6 and interleukin-11 support human osteoclast formation by a RANKL-independent mechanism. Bone 2003, 32, 1-7. [CrossRef]

49. Muruganandan, S.; Roman, A.A.; Sinal, C.J. Adipocyte differentiation of bone marrow-derived mesenchymal stem cells: Cross talk with the osteoblastogenic program. Cell. Mol. Life Sci. 2008, 66, 236-253. [CrossRef] [PubMed]

50. Cousins, J.M.; Petit, M.A.; Paudel, M.L.; Taylor, B.C.; Hughes, J.M.; Cauley, J.A.; Zmuda, J.M.; Cawthon, P.M.; Ensrud, K.E. Muscle power and physical activity are associated with bone strength in older men: The osteoporotic fractures in men study. Bone 2010, 47, 205-211. [CrossRef] [PubMed]

51. Kelley, G.A.; Kelley, K.S.; Tran, Z.V. Exercise and bone mineral density in men: A meta-analysis. J. Appl. Physiol. (1985) 2000, 88, 1730-1736.

52. Blanchet, C.; Giguere, Y.; Prud'homme, D.; Turcot-Lemay, L.; Dumont, M.; Leduc, G.; Cote, S.; Laflamme, N.; Rousseau, F.; Dodin, S. Leisure physical activity is associated with quantitative ultrasound measurements independently of bone mineral density in postmenopausal women. Calcif. Tissue Int. 2003, 73, 339-349. [CrossRef] [PubMed]

53. Wosk, J.; Voloshin, A. Wave attenuation in skeletons of young healthy persons. J. Biomech. 1981, 14, $261-267$. [CrossRef]

54. Yung, P.; Lai, Y.; Tung, P.; Tsui, H.; Wong, C.; Hung, V.; Qin, L. Effects of weight bearing and non-weight bearing exercises on bone properties using calcaneal quantitative ultrasound. Br. J. Sports Med. 2005, 39, 547-551. [CrossRef] [PubMed]

55. Riggs, B.L.; Khosla, S.; Melton, L.J. Sex steroids and the construction and conservation of the adult skeleton. Endocr. Rev. 2002, 23, 279-302. [CrossRef] [PubMed]

56. Chen, H.; Hardy, M.P.; Huhtaniemi, I.; Zirkin, B.R. Age-related decreased leydig cell testosterone production in the brown Norway rat. J. Androl. 1994, 15, 551-557. [PubMed]

57. Chen, H.; Hardy, M.P.; Zirkin, B.R. Age-related decreases in Leydig cell testosterone production are not restored by exposure to LH in vitro. Endocrinology 2002, 143, 1637-1642. [CrossRef] [PubMed]

58. Kaufman, J.M.; Vermeulen, A. The decline of androgen levels in elderly men and its clinical and therapeutic implications. Endocr. Rev. 2005, 26, 833-876. [CrossRef] [PubMed]

59. Sinnesael, M.; Boonen, S.; Claessens, F.; Gielen, E.; Vanderschueren, D. Testosterone and the male skeleton: A dual mode of action. J. Osteoporos. 2011, 2011, 240328. [CrossRef] [PubMed]

60. Chin, K.Y.; Ima-Nirwana, S. Sex steroids and bone health status in men. Int. J. Endocrinol. 2012, $2012,208719$. [CrossRef] [PubMed]

61. Falahati-Nini, A.; Riggs, B.L.; Atkinson, E.J.; O’Fallon, W.M.; Eastell, R.; Khosla, S. Relative contributions of testosterone and estrogen in regulating bone resorption and formation in normal elderly men. J. Clin. Investig. 2000, 106, 1553-1560. [CrossRef] [PubMed]

62. Chin, K.-Y.; Soelaiman, I.-N.; Mohamed, I.N.; Ahmad, F.; Ramli, E.S.M.; Aminuddin, A.; Ngah, W.Z.W. Sex hormones in Malay and Chinese men in Malaysia: Are there age and race differences? Clinics 2013, 68, 159-166. [CrossRef]

63. Winters, S.J.; Brufsky, A.; Weissfeld, J.; Trump, D.L.; Dyky, M.A.; Hadeed, V. Testosterone, sex hormone-binding globulin, and body composition in young adult African American and Caucasian men. Metabolism 2001, 50, 1242-1247. [CrossRef] [PubMed]

64. Chin, K.-Y.; Soelaiman, I.-N.; Mohamed, I.N.; Wan Ngah, W.Z. Serum testosterone, sex hormone-binding globulin and total calcium levels predict the calcaneal speed of sound in men. Clinics 2012, 67, 911-916. [CrossRef] 
65. Chin, K.-Y.; Soelaiman, I.-N.; Naina Mohamed, I.; Shahar, S.; Teng, N.I.M.F.; Suhana Mohd Ramli, E.; Ahmad, F.; Aminuddin, A.; Zurinah Wan Ngah, W. Testosterone is associated with age-related changes in bone health status, muscle strength and body composition in men. Aging Male 2012, 15, 240-245. [CrossRef] [PubMed]

66. Kuchuk, N.O.; van Schoor, N.M.; Pluijm, S.M.; Smit, J.H.; de Ronde, W.; Lips, P. The association of sex hormone levels with quantitative ultrasound, bone mineral density, bone turnover and osteoporotic fractures in older men and women. Clin. Endocrinol. (Oxf.) 2007, 67, 295-303. [CrossRef] [PubMed]

67. Kyvernitakis, I.; Saeger, U.; Ziller, V.; Bauer, T.; Seker-Pektas, B.; Hadji, P. The effect of age, sex hormones, and bone turnover markers on calcaneal quantitative ultrasonometry in healthy german men. J. Clin. Densitom. 2013, 16, 320-328. [CrossRef] [PubMed]

68. Vanderschueren, D.; Pye, S.; Venken, K.; Borghs, H.; Gaytant, J.; Huhtaniemi, I.; Adams, J.; Ward, K.; Bartfai, G.; Casanueva, F.; et al. Gonadal sex steroid status and bone health in middle-aged and elderly European men. Osteoporos. Int. 2010, 21, 1331-1339. [CrossRef] [PubMed]

69. Paller, C.J.; Shiels, M.S.; Rohrmann, S.; Basaria, S.; Rifai, N.; Nelson, W.; Platz, E.A.; Dobs, A. Relationship of sex steroid hormones with bone mineral density (BMD) in a nationally representative sample of men. Clin. Endocrinol. (Oxf.) 2009, 70, 26-34. [CrossRef] [PubMed]

70. Van den Beld, A.W.; de Jong, F.H.; Grobbee, D.E.; Pols, H.A.P.; Lamberts, S.W.J. Measures of bioavailable serum testosterone and estradiol and their relationships with muscle strength, bone density, and body composition in elderly men. J. Clin. Endocrinol. Metab. 2000, 85, 3276-3282. [CrossRef] [PubMed]

71. Khosla, S.; Melton, L.J.; Atkinson, E.J.; O’Fallon, W.M.; Klee, G.G.; Riggs, B.L. Relationship of serum sex steroid levels and bone turnover markers with bone mineral density in men and women: A key role for bioavailable estrogen. J. Clin. Endocrinol. Metab. 1998, 83, 2266-2274. [CrossRef] [PubMed]

72. Araujo, A.B.; Travison, T.G.; Leder, B.Z.; McKinlay, J.B. Correlations between serum testosterone, estradiol, and sex hormone-binding globulin and bone mineral density in a diverse sample of men. J. Clin. Endocrinol. Metab. 2008, 93, 2135-2141. [CrossRef] [PubMed]

73. Knapp, K.M. Quantitative ultrasound and bone health. Salud Pub. Mex. 2009, 51 (Suppl. 1), S18-S24. [CrossRef]

74. Greendale, G.A.; Tseng, C.-H.; Han, W.; Huang, M.-H.; Leung, K.; Crawford, S.; Gold, E.B.; Waetjen, L.E.; Karlamangla, A.S. Dietary isoflavones and bone mineral density during mid-life and the menopause transition: Cross-sectional and longitudinal results from the swan phytoestrogen study. Menopause 2015, 22, 279-288. [CrossRef] [PubMed]

75. Holick, M.F. Vitamin D: Evolutionary, physiological and health perspectives. Curr. Drug Targets 2011, 12, 4-18. [CrossRef] [PubMed]

76. Institute of Medicine. Dietary Reference Intakes for Calcium and Vitamin D; Institute of Medicine: Washington, DC, USA, 2011.

77. Abiaka, C.; Delghandi, M.; Kaur, M.; Al-Saleh, M. Vitamin D status and anthropometric indices of an Omani study population. Sultan Qaboos Univ. Med. J. 2013, 13, 224-231. [CrossRef] [PubMed]

78. Ardawi, M.S.; Sibiany, A.M.; Bakhsh, T.M.; Qari, M.H.; Maimani, A.A. High prevalence of Vitamin D deficiency among healthy Saudi Arabian men: Relationship to bone mineral density, parathyroid hormone, bone turnover markers, and lifestyle factors. Osteoporos. Int. 2012, 23, 675-686. [CrossRef] [PubMed]

79. Moy, F.M.; Bulgiba, A. High prevalence of Vitamin D insufficiency and its association with obesity and metabolic syndrome among Malay adults in Kuala lumper, Malaysia. BMC Public Health 2011, 11, 735. [CrossRef] [PubMed]

80. Ho-Pham, L.T.; Nguyen, N.D.; Lai, T.Q.; Eisman, J.A.; Nguyen, T.V. Vitamin D status and parathyroid hormone in a urban population in Vietnam. Osteoporos. Int. 2011, 22, 241-248. [CrossRef] [PubMed]

81. Chin, K.Y.; Ima-Nirwana, S.; Ibrahim, S.; Mohamed, I.N.; Wan Ngah, W.Z. Vitamin D status in Malaysian men and its associated factors. Nutrients 2014, 6, 5419-5433. [CrossRef] [PubMed]

82. Harris, S.S. Vitamin D and African Americans. J. Nutr. 2006, 136, 1126-1129. [PubMed]

83. Hawkins, R. Total 25-oh Vitamin D concentrations in Chinese, Malays and Indians. Ann. Lab. Med. 2013, 33, 156-158. [CrossRef] [PubMed]

84. Forrest, K.Y.; Stuhldreher, W.L. Prevalence and correlates of Vitamin D deficiency in us adults. Nutr. Res. 2011, 31, 48-54. [CrossRef] [PubMed] 
85. Jaaskelainen, T.; Knekt, P.; Marniemi, J.; Sares-Jaske, L.; Mannisto, S.; Heliovaara, M.; Jarvinen, R. Vitamin D status is associated with sociodemographic factors, lifestyle and metabolic health. Eur. J. Nutr. 2013, 52, 513-525. [CrossRef] [PubMed]

86. Dhanwal, D.K. Thyroid disorders and bone mineral metabolism. Indian J. Endocrinol. Metab. 2011, 15, S107-S112. [CrossRef] [PubMed]

87. Chin, K.-Y.; Ima-Nirwana, S.; Mohamed, I.N.; Aminuddin, A.; Johari, M.H.; Ngah, W.Z.W. Thyroid-stimulating hormone is significantly associated with bone health status in men. Int. J. Med. Sci. 2013, 10, 857. [CrossRef] [PubMed]

88. Kim, B.-J.; Lee, S.H.; Bae, S.J.; Kim, H.K.; Choe, J.W.; Kim, H.Y.; Koh, J.-M.; Kim, G.S. The association between serum thyrotropin (TSH) levels and bone mineral density in healthy euthyroid men. Clin. Endocrinol. (Oxf.) 2010, 73, 396-403. [CrossRef] [PubMed]

89. Kim, D.J.; Khang, Y.H.; Koh, J.-M.; Shong, Y.K.; Kim, G.S. Low normal TSH levels are associated with low bone mineral density in healthy postmenopausal women. Clin. Endocrinol. (Oxf.) 2006, 64, 86-90. [CrossRef] [PubMed]

90. Grimnes, G.; Emaus, N.; Joakimsen, R.M.; Figenschau, Y.; Jorde, R. The relationship between serum TSH and bone mineral density in men and postmenopausal women: The Tromsø study. Thyroid 2008, 18, 1147-1155. [CrossRef] [PubMed]

91. Morris, M.S. The association between serum thyroid-stimulating hormone in its reference range and bone status in postmenopausal American women. Bone 2007, 40, 1128-1134. [CrossRef] [PubMed]

92. Morimura, T.; Tsunekawa, K.; Kasahara, T.; Seki, K.; Ogiwara, T.; Mori, M.; Murakami, M. Expression of type 2 iodothyronine deiodinase in human osteoblast is stimulated by thyrotropin. Endocrinology 2005, 146, 2077-2084. [CrossRef] [PubMed]

93. Abe, E.; Marians, R.C.; Yu, W.; Wu, X.-B.; Ando, T.; Li, Y.; Iqbal, J.; Eldeiry, L.; Rajendren, G.; Blair, H.C.; et al. TSH is a negative regulator of skeletal remodeling. Cell 2003, 115, 151-162. [CrossRef]

94. Baliram, R.; Latif, R.; Berkowitz, J.; Frid, S.; Colaianni, G.; Sun, L.; Zaidi, M.; Davies, T.F. Thyroid-stimulating hormone induces a WNT-dependent, feed-forward loop for osteoblastogenesis in embryonic stem cell cultures. Proc. Natl. Acad. Sci. USA 2011, 108, 16277-16282. [CrossRef] [PubMed]

95. Hase, H.; Ando, T.; Eldeiry, L.; Brebene, A.; Peng, Y.; Liu, L.; Amano, H.; Davies, T.F.; Sun, L.; Zaidi, M.; et al. $\mathrm{TNF} \alpha$ mediates the skeletal effects of thyroid-stimulating hormone. Proc. Natl. Acad. Sci. USA 2006, 103, 12849-12854. [CrossRef] [PubMed]

96. Laron, Z. Insulin-like growth factor 1 (IGF-1): A growth hormone. Mol. Pathol. 2001, 54, 311-316. [CrossRef] [PubMed]

97. Gillberg, P.; Olofsson, H.; Mallmin, H.; Blum, W.F.; Ljunghall, S.; Nilsson, A.G. Bone mineral density in femoral neck is positively correlated to circulating insulin-like growth factor (IGF)-I and IGF-binding protein (IGFBP)-3 in Swedish men. Calcif. Tissue Int. 2002, 70, 22-29. [CrossRef] [PubMed]

98. Krassas, G.; Papadopoulou, P.; Koliakos, G.; Konstantinidis, T.; Kalothetou, K. Growth hormone, insulin growth factor-1, and IGF binding protein-3 axis relationship with bone mineral density among healthy men. Arch. Androl. 2003, 49, 191-199. [CrossRef] [PubMed]

99. Langlois, J.A.; Rosen, C.J.; Visser, M.; Hannan, M.T.; Harris, T.; Wilson, P.W.F.; Kiel, D.P. Association between insulin-like growth factor I and bone mineral density in older women and men: The Framingham heart study. J. Clin. Endocrinol. Metab. 1998, 83, 4257-4262. [CrossRef] [PubMed]

100. Barrett-Connor, E.; Goodman-Gruen, D. Gender differences in insulin-like growth factor and bone mineral density association in old age: The Rancho Bernardo study. J. Bone Min. Res. 1998, 13, 1343-1349. [CrossRef] [PubMed]

101. Nakasaki, M.; Yoshioka, K.; Miyamoto, Y.; Sasaki, T.; Yoshikawa, H.; Itoh, K. IGF-I secreted by osteoblasts acts as a potent chemotactic factor for osteoblasts. Bone 2008, 43, 869-879. [CrossRef] [PubMed]

102. Tiago, D.M.; Cancela, M.L.; Laize, V. Proliferative and mineralogenic effects of insulin, IGF-1, and vanadate in fish osteoblast-like cells. J. Bone Min. Metab. 2011, 29, 377-382. [CrossRef] [PubMed]

103. Zhang, M.; Xuan, S.; Bouxsein, M.L.; von Stechow, D.; Akeno, N.; Faugere, M.C.; Malluche, H.; Zhao, G.; Rosen, C.J.; Efstratiadis, A.; et al. Osteoblast-specific knockout of the insulin-like growth factor (IGF) receptor gene reveals an essential role of IGF signaling in bone matrix mineralization. J. Biol. Chem. 2002, 277, 44005-44012. [CrossRef] [PubMed] 
104. Cavani, F.; Giavaresi, G.; Fini, M.; Bertoni, L.; de Terlizzi, F.; Barkmann, R.; Cane, V. Influence of density, elasticity, and structure on ultrasound transmission through trabecular bone cylinders. IEEE Trans. Ultrason. Ferroelectr. Freq. Control 2008, 55, 1465-1472. [CrossRef] [PubMed]

105. Guglielmi, G.; de Terlizzi, F. Quantitative ultrasound in the assessment of osteoporosis. Eur. J. Radiol. 2009, 71, 425-431. [CrossRef] [PubMed]

106. Padilla, F.; Jenson, F.; Bousson, V.; Peyrin, F.; Laugier, P. Relationships of trabecular bone structure with quantitative ultrasound parameters: In vitro study on human proximal femur using transmission and backscatter measurements. Bone 2008, 42, 1193-1202. [CrossRef] [PubMed]

107. Moayyeri, A.; Adams, J.; Adler, R.; Krieg, M.A.; Hans, D.; Compston, J.; Lewiecki, E. Quantitative ultrasound of the heel and fracture risk assessment: An updated meta-analysis. Osteoporos. Int. 2012, 23, 143-153. [CrossRef] [PubMed]

(c) 2016 by the authors; licensee MDPI, Basel, Switzerland. This article is an open access article distributed under the terms and conditions of the Creative Commons Attribution (CC-BY) license (http://creativecommons.org/licenses/by/4.0/). 